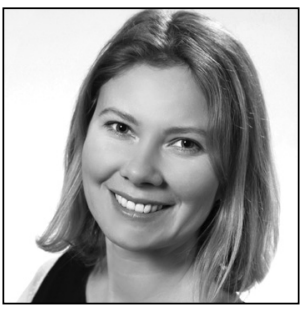

Agne Kalson

Doctoral student University of Tartu

\title{
Special Job-sharing Regulation - a Promoter of Flexible Working?
}

\section{Introduction}

Economic-demographic changes taking place in the European Union (EU) present a challenge to standard full-time employment. With regard to contemporary employment relationships, standard full-time employment may not be enough to meet everybody's needs in the labour market. Various needs have led to diverse new ways to organise work, including working time, and these represent a growing trend in the EU. Since 2000, the European Foundation for the Improvement of Living and Working Conditions (Eurofound) has detected nine new forms of employment in the EU. ${ }^{*}$ Job-sharing is one of the new forms of work listed in the Eurofound report.

Job-sharing (working in pairs or work that involves 'twinning') was introduced first in the United States of America (USA) in the '6os and was characterised mainly through flexibility in the organisation of working time, with 'two people sharing the same employment relationship corresponding to one full-time job'. ${ }^{2}$ Teaching and nursing were among the first professional positions to be shared thus, filled largely by women wishing to combine a career and family life. ${ }^{*} 3$

Benefits offered by job-sharing caused this alternative employment form to spread from the USA to Europe. In Europe, the concept of job-sharing was introduced initially during recessionary times in the 1980 s and the early 1990s. In those times, Europe faced a tremendous increase in unemployment rates. As a remedy, work-sharing was proposed by the Organisation for Economic Co-operation and Development (OECD) Europe. The forms of work-sharing used thus far have been job-sharing (filling a single work post with more than one person) and 'trading hours for jobs' (reducing working time for workers under contract, to create jobs). ${ }^{* 4}$

Nowadays, job-sharing is distinguished from work-sharing in that the latter is a more generic concept applied for any steps taken to redistribute work in order to reduce unemployment ${ }^{*}{ }^{5}$ and usually refers to an

1 Eurofound. New forms of employment, pp. 1-2. Available at https://www.eurofound.europa.eu/sites/default/files/ef_publication/field_ef_document/ef1461en.pdf (most recently accessed on 18.4.2017).

2 S. Isola. Il contratto di job sharing ['The job-sharing contract'], p. 6. Available at http://www.tosc.cgil.it/ftp/centrodocumentazione/files/tesi_isola.pdf (most recently accessed on 18.4.2017) (in Italian).

3 K. Marshall. Job sharing, p. 6. Available at http://ivt.crepuq.qc.ca/popactive/documentation2002_A/1997/ pear1997009002s2a01.pdf (most recently accessed on 18.4.2017).

4 T. Miyakoshi. The efficacy of job-sharing policy. - Applied Economics Letters 8 (2001) / 7, pp. 437-439. - DOI: http:// dx.doi.org/10.1080/135048501750267105.

5 J.G. Pesek, C. McGee. An analysis of job sharing, full-time and part-time work arrangements: One hospital's experience. American Business Review 7 (1989) / 2, pp. 34-40. 
organisation's short-term response to a particular economic situation. ${ }^{* 6}$ Many countries facilitate the use of work-sharing as a labour-market policy tool aimed at preserving existing jobs or creating new ones. Unlike work-sharing, job-sharing is generally not used as a measure to avoid layoffs, retain employees by spreading less work among an existing workforce (as an alternative to job losses), or increase employment. ${ }^{*}$ Jobsharing is seen in the EU primarily as one of the new flexible work paradigms that can aid in combating the age-related problems arising in the EU labour market (associated with demographic changes) and offering working-time flexibility for those who are not open to full-time employment.

In countries where various new forms of work have existed for some time or are widespread or deliberately promoted by the government, specific regulation has been adapted to unify the application practices. For example, job-sharing as a new form of work has specific regulation in Germany, Slovakia, Hungary ${ }^{*}$, and Lithuania. The Government of the Republic of Lithuania set a goal of modernising labour regulations and increasing the associated flexibility. A new Labour Code ${ }^{*} 9$ was adopted in Lithuania that introduced new forms of work, including job-sharing. Italy had a specific regulation on job-sharing until it was abolished by the 2015 labour reforms referred to as the Jobs Act. ${ }^{* 10}$ The Association for International and Comparative Studies in Labour and Industrial Relations (ADAPT)'s professional fellow A. Tea commented on the abolishment of the job-sharing labour form in Italy as follows: the repealing of job-sharing provisions is not acceptable since it's a flexible tool and an expression of labour modernization and contractual flexibility arrangement, as shown by the experience of other European countries. On the contrary, the Italian legislator should have clarified current legislation regulating job sharing. ${ }^{*}{ }^{11}$

There are various European Union member states (hereinafter 'MSs') where no specific regulation of job-sharing exists but the new employment form is nevertheless practised. ${ }^{*} 2$ The exploitation of new forms of work in the situation wherein regulation specific to it is absent has raised questions over whether and under what conditions it is reasonable to allow parties to an employment relationship to enter into agreement on new forms of work. In discussion of the optional regulations, it has been considered essential to guarantee the parties the desired flexibility, workplace safety, and the protection of employment rights.

The need for additional flexibility in the form of job-sharing has forced parties to an employment relationship in the context of absence of special job-sharing regulations to operate within the framework of standard labour regulations. National standard labour norms may provide some guidelines on the application of new forms of work, but concern remains as to whether the standard labour regulation is sufficient and clear enough to make the entrance into new forms of employment (including job-sharing) effective.

The goal set for this paper was to determine from the example of job-sharing (as a new form of work) and Estonian ${ }^{*}{ }^{13}$ labour law whether the absence of special regulation on national level precludes or unreasonably restricts the opportunities of parties to an employment relationship to increase the flexibility of that relationship and enter into a corresponding regime (here, one for job-sharing) in comparison to those

6 B. Olmsted. Job sharing: An emerging work-style. - International Labour Review 118 (1979) / 3, pp. 283-297, on p. 284.

7 ILO. Work-sharing and job-sharing, p. 1. Available at http://www.ilo.org/wcmsp5/groups/public/---ed_protect---/protrav/ ---travail/documents/publication/wcms_169673.pdf (most recently accessed on 18.4.2017).

8 Part II, Chapter XV of the new Labour Code regulates special employment relationships (including job-sharing), which were mostly unknown in Hungary before 2012. For more information, consult J.K. Járai. Modernising of work organization: New forms of employment in Hungary, p. 4. Available at https://www.employment.gov.sk/files/slovensky/ministerstvo/ medzinarodna-spolupraca/dynamicky-vysehrad/modernising-work-organization.pdf (most recently accessed on 18.4.2017).

9 Lietuvos Respublikos darbo kodekso patvirtinimo, isigaliojimo ir igyvendinimo istatymas (Law on the Approval, Entry into Force, and Implementation of the Labour Code of the Republic of Lithuania), of 14 September 2016, No. XII-2603 (in Lithuanian). The new Labour Code, as adopted in Lithuania on 14.9.2016, came into force on 1.7.2017.

10 OECD Economic Surveys: Italy, p. 9. Available at http://www.oecd.org/eco/surveys/Overview_Italy_2015_ENG.pdf (most recently accessed on 18.4.2017).

11 A. Tea. 'The (bad) end of Job Sharing': Another paradox of the Italian labour (market) reform that aims at the future but recedes into the past..., p. 4. Available via http://adapt.it/englishbulletin/wp/the-bad-end-of-job-sharing-another-paradox-of-the-italian-labour-market-reform-that-aims-at-the-future-but-recedes-into-the-past/ (most recently accessed on 18.4.2017).

12 For example, job-sharing has recently emerged as a company practice in the Czech Republic and Poland without being specifically regulated. For more details, see the Eurofound piece cited in Note 1, p. 31.

13 Estonian labour regulation does not prohibit the use of job-sharing; neither does the national law contain specific regulation of job-sharing. 
countries where special regulation does exist. The results presented in the article should enable other MSs to decide on the necessity of special job-sharing regulation.

The methods used for the study are of a comparative, historical, and analytical nature. The work is based on the examination of Estonian labour law. In addition, references are made to national laws wherein job-sharing as an employment form was (Italy) and is (Germany, Slovakia, Hungary, and Lithuania) specifically regulated on national level.

The comparative analyses of Italian, German, Slovakian, Hungarian and Lithuanian job-sharing regulations enable covering the theme from the perspective of all national normative sources now available in the EU. References to all of the job-sharing regulations and practices of EU countries where job-sharing is specifically stipulated aid in offering solutions for the problems detected with respect to the associated research area.

\section{Plurality of definitions}

Introducing new forms of employment on national level enables one to increase the flexibility of the labour market and modernise it by giving parties to an employment relationship additional opportunities to organise work and working time. The European Commission has issued a Green Paper, 'Modernising Labour Law to Meet the Challenges of the 21st Century ${ }^{*}{ }^{14}$, wherein the need to encourage flexible work relations and modernise labour-law regulations has been emphasised.

The process of modernisation of labour laws among MSs has been erratic. Some MSs have modernised their labour regulations so as to enable the concerned parties to apply job-sharing, while other MSs prefer to stay rather conservative in the process of introducing any new form of work. To enable employed persons or prospective employed persons to enter into job-sharing, it is considered essential from the uniformity standpoint to provide its definition on the national level. For example, in Estonia, where job-sharing is not regulated on the national level, there is no single definition available for this new form of work. That enables parties to an employment relationship to give the term 'job-sharing' its own meaning, which can vary from each employment relationship to the next.

The fact that job-sharing can be defined in various ways is concretised through the comparative analysis of job-sharing definitions on national and supranational levels. For example, various supranational organisations have defined job-sharing through its common characteristics. For instance, the International Labour Organization (ILO) defines job-sharing as 'a voluntary arrangement whereby two persons take joint responsibility for one full-time job and divide the time they spend on it according to specific arrangements made with the employer. ${ }^{*}{ }^{15}$ Eurofound has defined job-sharing as 'an employment relationship in which one employer hires several workers, but normally just two, to fill a single full-time position'. ${ }^{* 16}$

Not many MSs have made efforts to establish a definition for job-sharing on national level. In Italy, for example, job-sharing was regulated at first by articles 41 to 45 of Legislative Decree 276/2003. ${ }^{* 17}$ Article 41's first sentence stipulated that 'the contract for job-sharing is a special employment contract by means of which two employees jointly assume the fulfilment of a unique and identical work obligation'. The characteristic element of this type of contract was deemed to be the presence of a contractual obligation shared by two obligors, who were bound firmly to fulfil that obligation. ${ }^{*} 18$ The formality requirements for such a contract included a written form wherein certain elements, such as the task share and the time allocation, had to be specified in detail and communicated to the employer. ${ }^{*} 9$ In Italy, employers can no longer resort to a 'job-sharing model' unless it would be likely to be possible through an atypical contract, as addressed by Article 1322 of the Italian Civil Code. ${ }^{*}$

14 Green Paper 'Modernising labour law to meet the challenges of the 21st century'. Available at http://www.europarl.europa.eu/ RegData/etudes/etudes/join/2007/385633/IPOL-EMPL_ET(2007)385633_EN.pdf (most recently accessed on 18.4.2017).

15 ILO (see Note 7), p. 1.

16 Eurofound (see Note 1), p. 31.

17 Decreto Legislativo 10 settembre 2003, n. 276 (Legislative Decree of 10 September 2003, no. 276). - Gazzetta Ufficiale N. 235 del 9 ottobre 2003 (in Italian).

18 S. Isola (see Note 2), p. 24.

19 Decreto Legislativo 10 settembre 2003 (see Note 17), Art. 42.

20 A. Tea (see Note 11), p. 3. 
The Italian and Lithuanian definitions for job-sharing are similar, as both allow sharing a job only between two employees. Under a Lithuanian job-sharing employment contract, 'two employees can agree with the employer on sharing one job position'. ${ }^{{ }^{*} 1}$ It is noteworthy that other MSs where job-sharing is regulated on national level have not limited the number of employees in the job-sharing scheme. For example, the Slovakian Labour Code ${ }^{{ }^{2} 22}$ defines job-sharing as 'a job in which employees in an employment relationship with reduced working time themselves distribute amongst themselves the working time and the job description appertaining to the job'. In Germany ${ }^{*}{ }^{23}$, the employer and employee may agree that a workplace is shared by two or more employees, and in Hungary ${ }^{* 24}$, the employer may conclude an employment contract with several workers for carrying out the functions for a job jointly.

Job-sharing can be distinguished as defined mainly in terms of mutual work obligations of the job-sharers and seldom through the joined organisation of working time (as in Slovakia). According to definitions given by supranational organisations, only full-time work can be shared among the job-sharers; thereby, the possibility of sharing a part-time job is ruled out. National regulations have side-stepped this limitation and allow sharing any kind of job, even a part-time one.

The comparative analysis points to a plurality of elements through which job-sharing as a new type of work can be identified. In Estonia, where no definition for job-sharing exists on national level, any of various agreements can be reached that provide a unique definition for it, specific to the employment relationship. The plurality of definitions may lead to a situation wherein people in various employment relationships are treated differently while working under the same actual form of work (here, job-sharing). A corresponding situation can cause confusions in practice and diminish the willingness of parties to an employment relationship to apply job-sharing.

Applying an unambiguous definition for job-sharing enables one to distinguish job-sharing from other forms of work and practices and thereby ensure harmonised application on national level. In those MSs where no special job-sharing regulation exists, the answer for harmonised implementation of job-sharing may lie in collaboration with social partners in MSs where the industrial relations are well developed. In MSs where the role of such social partners in the employment relationships is marginal, as it is in Estonia, rectification may not result, however. From the flexibility standpoint, it is important to strengthen the industrial relations and hence provide possibilities for employees and employers to agree on the definition and application of job-sharing via collective agreements.

\section{Regulation of part-time work as an effective entry point to addressing job-sharing?}

Job-sharing has elements in common with standard part-time work. This has made it possible for various MSs and supranational organisations to define job-sharing as a form of part-time work. ${ }^{* 25}$ For example, the ILO considers job-sharing to be a form of part-time work, stipulating that the 'part-time work can take special forms, such as job sharing (one full-time job is split into two part-time jobs)'. ${ }^{26}$

Irrespective of its origin, job-sharing differs from traditional part-time work in several ways. For example, job-sharing is unlike part-time work in that it can be applied for specific positions wherein the working time (for reasons related to the nature of the work or the employer's desire to maintain the job in its

21 Labour Code of Lithuania (see Note 9), Art. 93, para. 1.

22 Zákonnik práce. Zákon č. 311/2001 Z. Z. (Labour Code of Slovakia). - Zbierka zákonov SR 311/2001 Z. z. znenie 18.06.2016 (in Slovakian), Art. 49a. English text available at http://www.ilo.org/dyn/eplex/docs/50/labour-code-full-wordingjanuary-2012.pdf (most recently accessed on 18.4.2017).

23 Stipulated specifically in the Act on Part-Time and Fixed-Term Contracts (Teilzeit- und Befristungsgesetz), Art. 13, Section 1, 'Arbeitgeber und Arbeitnehmer können vereinbaren, dass mehrere Arbeitnehmer sich die Arbeitszeit an einem Arbeitsplatz teilen (Arbeitsplatzteilung)'.

24 The Hungarian Labour Code: Törvény a munka törvénykönyvéröl. - optiJUS 2012.06.25; optiJUS 2017.01.01 (in Hungarian), Section 194, Subsection 1. English text available at http://www.ilo.org/dyn/travail/docs/2557/Labour\%20Code.pdf (most recently accessed on 18.4.2017).

25 Eurofound (see Note 1), p. 31.

26 ILO. Part-time work, p. 1. Available at http://www.ilo.org/wcmsp5/groups/public/---ed_protect/---protrav/---travail/ documents/publication/wcms_170717.pdf (most recently accessed on 18.4.2017). 
entirety) cannot be reduced to less than hours per day (40 hours per week) or divided between multiple part-time employees. Also, an obligation to co-operate and communicate distinguishes job-sharers from part-time workers. ${ }^{*} 7$

Special features and often the special job-sharing regulation in place differentiate job-sharing from standard part-time work. For example, the job-sharing arrangement in Italy was determined by the labour norms to entail a special type of employment contract, with its own characteristics that distinguished it from the other types of contracts. In Italy, job-sharing as a special type of employment was regulated separately from part-time work. The aim of regulating job-sharing separately from part-time work was a clear indication that part-time employment contracts were not a suitable option for the case of job-sharing. The latter approach can be distinguished in the Labour Code of Lithuania and of Hungary, wherein job-sharing is treated as involving a new type of contract and not as a form of part-time work. A different approach can be detected in Slovakia and Germany. In Slovakia, job-sharing is classified in the Labour Code as a form of employment relationship with reduced working time, and job-sharers in Germany are considered part-time employees within the meaning of the provisions of the Part-Time and Limited Term Employment Act. ${ }^{*} 8$

In Estonia, job-sharing as a new form of work in the legislative domain is unknown. There are no special provisions in Estonian labour law regulating job-sharing agreements. According to the general principle of law, regulation of contracts not regulated specifically in the laws is implemented in accordance with analogy to existing contract types. ${ }^{* 29}$ The features common to part-time work enable parties to an employment relationship to apply job-sharing via the regulation of part-time work. Employers are free to enter into part-time work agreements with each job-sharer and negotiate the contract terms in either employment contract. Therefore, the absence of special job-sharing regulation cannot impede the parties' entry into a job-sharing regime.

In Estonia, when treated as part-time workers, job-sharers have to be guaranteed the same rights as full-time workers. For example, the amount of annual leave ( 28 calendar days) has to be the same in Estonia between full-time workers and part-time workers. ${ }^{*}{ }^{30}$ This means that each job-sharer when treated as a part-time worker has to be guaranteed annual holiday of 28 calendar days. In MSs where special job-sharing regulation exists, the holiday time is generally aggregated and allocated on a pro rata basis, which provides employers with a substantial cost-related advantage relative to Estonian practice.

The study indicates in the case of Estonian labour law that the part-time work regulation when directly applied to job-sharing may be beneficial for job-sharers, but from the perspective of employers' economic costs, entrance into a job-sharing regime may become irrational. It has been detected that the direct application of part-time work regulation does not support parties' decision to enter into a job-sharing arrangement. The benefits arising from job-sharing have to be mutual for the parties to an employment relationship to choose this new form of work over the traditional options. The cost-related constraints can be eliminated only by stipulating special job-sharing provisions on national level. Through national support and special regulation, job-sharing as a new form of work can be made acceptable for both parties.

\section{Variety of contracts for entering job-sharing}

Traditionally, employment contracts are formed between one employer and one employee. The emergence of job-sharing has created a situation wherein two or more employees are related to one job. The plurality of the parties is considered a new situation for many MSs, Estonia among them.

Eurofound has described, in the report on new forms of employment, two distinct contractual options related to job-sharing. National practices encompass some MSs wherein all job-sharers have their own

27 B. Olmsted (see Note 6), p. 284.

28 Gesetz über Teilzeitarbeit und befristete Arbeitsverträge (Teilzeitund Befristungsgesetz - TzBfG) (Part-Time and Limited Term Employment Act). - 21.12.2000 (BGBl. I S. 1966), 20.12. 2011 (BGBl. I S. 2854) (in German). English text available at http:// www.mayr-arbeitsrecht.de/wp-content/uploads/2016/05/Part-Time-and-Limited-Term-Employment-Act.pdf (most recently accessed on 18.4.2017).

29 P. Varul et al. Võlaõigusseadus I. Kommenteeritud väljaanne (Law of Obligations Act I, commented edition). Tallinn 2016, p. 5 (in Estonian).

30 Töölepingu seadus (Employment Contracts Act), ECA). - RT I 2009, 5, 35; RT I, 7.12.2016, 1 (in Estonian), Section 55. English text available at https://www.riigiteataja.ee/en/eli/530122016002/consolide (most recently accessed on 1.5.2017). 
individual contract of employment and also MSs in which job-sharing is based on a single contract covering two or more workers. ${ }^{*} 1$

According to the ILO, a commonplace form of job-sharing is to split one full-time job into two part-time jobs. ${ }^{{ }^{*} 2}$ Entering into a separate employment contract with each job-sharer is practised in, for example, Germany, Lithuania, and Slovakia. In Germany, an employer wishing to create shareable jobs has to enter into an employment contract with at least two or more prospective part-time employees, who will share a full-time job. The new Lithuanian Labour Code ${ }^{*} 33$ stipulates that in both employment contracts the type of the employment contract, [the] identity of the other employee and his contact details, [and] the employee's rate of working time (the number of working hours per week) shall be indicated'. ${ }^{*} 3$ In Slovakia too, each employee-to-be is expected to enter into an individual agreement on job-sharing. The Slovakian legislator emphasises that 'an agreement on the assignment of an employee to a job sharing concluded between an employer and an employee must be done in writing, otherwise it shall be invalid'. ${ }^{35}$

Unlike in Germany and Slovakia, job-sharing in Italy was regulated separately from part-time work and other types of contracts. It was determined on the national level that 'the contract on job-sharing is a special employment contract by means of which two employees jointly assume the fulfilment of a unique and identical work obligation'. ${ }^{*}{ }^{6}$ Prospective job-sharers in Italy were expected to enter into a joint employment contract, prescribing the most important employment conditions concerning each job-sharer. The characteristic element of this type of contract was the presence of a contractual obligation shared by two obligors, who were bound firmly to the fulfilment of one job. ${ }^{*} 37$ The formality requirements of such a contract included a written form wherein certain elements, such as the task share and the time allocation, had to be specified in detail and communicated to the employer. ${ }^{*} 38$

In a similarity to Italian practice, the plurality of parties to an employment relationship, and the right to enter into one employment contract with several workers, is coherently stipulated in Hungarian labour law. It is determined that 'the employer may conclude an employment contract with several workers for carrying out the functions of a job jointly'. ${ }^{*} 39$

In Estonia, it is common to have only one employer and one employee on each side of the employment contract. A single employment contract with two or more employees or employers is not directly allowed; neither is it prohibited. The right to enter into an employment contract that involves multiple employees or employers is not regulated in the Estonian Employment Contracts Act (ECA). Leaving the matter unregulated does not mean that the parties entering an employment relationship are not allowed to conclude an employment contract with multiple employees or employers.

The author concludes that the corresponding right (to enter into an employment contract involving multiple employees or employers) can be derived from various legal acts. ${ }^{*}{ }^{\circ 0}$ In the explanations to the ECA it has been stipulated that for those questions not answered through regulation in the ECA, the general part of the Estonian Law of Obligations Act ${ }^{*} 41$ (LOA) and the General Part of the Civil Code Act ${ }^{*} 4$ apply. ${ }^{*} 43$ The general part of the LOA makes it possible for parties entering an employment relationship to enter into a single job-sharing contract. The position is supported by the definition of 'contract' provided by the LOA, according to which 'a contract is a transaction between two or more persons (parties) '. ${ }^{44}$ Therefore, in every

31 Eurofound (see Note 1), p. 31.

32 ILO (see Note 7), p. 1

33 Labour Code of Lithuania (see Note 9).

34 Ibid., Art. 93, Section 2.

35 Labour Code of Slovakia (see Note 22), Section 49a, Subsection 3.

Decreto Legislativo 10 settembre 2003 (see Note 17), Art. 41.

S. Isola (see Note 2), p. 24.

Decreto Legislativo 10 settembre 2003 (see Note 17), Art. 42.

Hungarian Labour Code (see Note 24), Section 194, Subsection 1.

40 For example, from the Estonian Employment Contracts Act, Law of Obligations Act, and General Part of the Civil Code Act.

41 Võlaõigusseadus (Law of Obligations Act). - RT I 2001, 81, 487; 31.12.2016, 1 (in Estonian). English text available at https:// www.riigiteataja.ee/en/eli/524012017002/consolide (most recently accessed on 18.4.2017).

42 Tsiviilseadustiku üldosa seadus (General Part of the Civil Code Act). - RT I 2002, 35, 216; RT I, 12.3.2015, 5 (in Estonian). English text available at https://www.riigiteataja.ee/en/eli/528082015004/consolide (most recently accessed on 1.5.2017).

43 E. Käärats et al. Töölepingu seadus. Selgitused töölepingu seaduse juurde ['Employment Contracts Act - Explanations to the Employment Contracts Act']. Juura 2013 (in Estonian), p. 16.

44 Law of Obligations Act, Section 8, Subsection 1. 
obligatory relationship there have to be at least two parties, and also it is allowed to have multiple parties on each side of the contract. The principle of plurality of parties applies, through the general part of the LOA, to employment relationships, referring to the possibility of entering into a single employment contract with multiple employees or employers.

The author's position can be confirmed from the perspective of contracts of partnership ${ }^{*} 4$. Under a contract of partnership, the partners (two or more) can enter into an employment contract only jointly, because the consent of all the partners is needed for any transaction to be concluded - including employment contracts. Additionally, the example confirms the right of the parties entering an employment relationship to enter into a single contract with multiple employees or employers.

The comparative study indicates that special job-sharing regulations have a tendency to prescribe the contract type that the parties have to utilise if wishing to enter into a job-sharing arrangement. The choice of contract option is either a single employment contract or an option for each employee to sign a separate employment contract with the employer. Thereby, the special regulation reduces the range of options to one. In Estonia, where no special job-sharing regulation exists, the parties entering an employment relationship are allowed to choose either form of employment contract (separate or joint). Compared to the MSs where special job-sharing regulation exists, Estonia with its general labour law offers job-sharers more flexibility in the context of contractual choice. Plurality of contractual choice can increase the parties' options for entering a job-sharing regime, but, that said, at the same time it can also promote unharmonised practices in job-sharing and lead to confusion related to the management of a joint employment contract.

\section{Constraints related to transferring to job-sharing}

Ability to enter into a job-sharing regime is directly affected by the norms stipulated on national level. Constraints to entrance to a job-sharing arrangement may be validated deliberately at the national level or, alternatively, proceed from general labour regulations. Unreasonable limitations hinder opportunities to participate in a job-sharing regime and to achieve the required flexibility in the employment relationship.

Of the MSs compared here, Slovakia with its Labour Code does not set any restrictions on entering into a job-sharing regime. The parties' agreement is the only criterion that has to be met. ${ }^{*} 46$ Mutual agreement is considered the main criterion also in Hungary, Lithuania, and Italy. The Italian Ministry of Labour issued a communication in 1998 clarifying the following: job-sharing arrangements 'can be applied to all categories of workers without any kind of constraints or limitations'. ${ }^{47}$ Mutual agreement is essential also in Germany when, at the beginning of the employment relationship, the parties decide to apply job-sharing. In addition, Estonian general labour law does not foresee any limitations for entering into a job-sharing regime under regulations pertaining to part-time work. The parties' mutual agreement is the only criterion that has to be met, in an echo of the comparable MSs wherein special job-sharing regulation exists.

Normative limitations can appear when an employee requests to move over from full-time work to a job-sharing regime. In Germany, the limitations established for part-time work extend to job-sharing. The duration of employment and the number of employees in the enterprise determine an employee's right to be transferred from full-time work to job-sharing arrangements. In principle, only employees who have worked more than six months in a company with more than 15 employees have the right to claim a reduction of working time in the form of job-sharing. ${ }^{*}{ }^{48}$ It has to be noted that the limitation does not preclude the right of parties to an employment relationship to negotiate more favourable terms for the employees than stipulated in the law.

The right to request job-sharing after having worked in the enterprise for more than six months enables maintaining stability in the organisation of work. The limitation related to the number of employees of the enterprise may place employees of small enterprises in a less favourable position than employees with

45 Law of Obligations Act, Part 7.

46 Labour Code of Slovakia (see Note 22), Section 49, Subsection 1.

47 Eurofound. Job-sharing introduced in Italy, p. 1. Available at https://www.eurofound.europa.eu/observatories/eurwork/ articles/job-sharing-introduced-in-italy (most recently accessed on 18.4.2017).

48 Part-Time and Limited Term Employment Act of Germany (see Note 28), Section 8, subsections 1 and 7. 
larger enterprises. For example, in Estonia, where most of the enterprises (90\%) are classified as microenterprises ${ }^{*} 49$, with fewer than 10 employees ${ }^{*}{ }^{*}$, the limitations as stipulated in Germany would extensively affect employees' options to request job-sharing. Often, small enterprises are the ones that need additional flexibility to manage the workload with the existing number of employees. Limiting the options for them would influence a considerable number of employees. To treat micro-enterprises any differently would demand reasonable cause.

Entering into a job-sharing regime may be impeded also by the employer, whose consent is needed for employees to be transferred from full-time work to job-sharing. For example, the labour regulations in Slovakia, Hungary, Italy, and Estonia do not stipulate the conditions in which the refusal of workingtime reduction (i.e., refusal of an employee request to apply job-sharing) is justified. This state of affairs may encourage employers to exert the force of their will in the decision-making process, in the form of unjustified refusal, and thereby limit employees' option of entering a job-sharing relationship. Germany has solved the problem by giving the employer the right to decline a request for job-sharing only if an operations-related reason for doing so is given. Such reasons exist in particular if the reduction of working time would fundamentally impair the establishment's organisation, work processes, or safety or would cause the establishment to incur unreasonable costs. ${ }^{* 1}$ Employers' obligation to justify the refusal by way of operations-based reasons increases employees' opportunities to enter into a job-sharing regime. German practice points to potential for increasing employees' chances of entering job-sharing through special regulation. Employees can have certainty of the conditions with which their job-sharing requests are managed and insist on the employer's actions complying with the norms. In comparison to German practice, certainty is not guaranteed - and entrance into a job-sharing regime is limited - in those MSs (Estonia among them) where employers have been given the freedom to decline employee applications for any reason. The German practice should be followed so that employers do not exercise 'self-will' with respect to the transfer process and so as to increase employees' opportunities to enter into job-sharing.

\section{Conclusions}

This article was prepared to examine the example of job-sharing (as a new form of work) and Estonian labour law for purposes of ascertaining whether the absence of special job-sharing regulation on national level precludes or unreasonably restrains the opportunities for parties wishing to enter an employment relationship to increase the flexibility by entering a job-sharing arrangement, as compared to those countries where special job-sharing regulation exists.

The comparative analysis indicates a plurality of elements through which job-sharing as a new type of work can be identified. In Estonia, where no definition for job-sharing exists on national level, agreements of various sorts can be reached. Hence, a unique definition of job-sharing can be supplied for every individual employment relationship. The plurality of definitions may lead to a situation wherein parties to employment relationships of various sorts are treated differently while actually applying a form of work that is defined in a uniform way in other MSs (i.e., job-sharing).

It has been detected that the direct application of part-time work regulation does not support the parties' choice to enter into job-sharing. The cost-related constraints can be eliminated only by stipulating special job-sharing provisions at the national level.

The comparative study indicates that special job-sharing regulation tends to prescribe a certain type of contract that the parties have to follow if wishing to enter into a job-sharing regime. The option may be either a single employment contract or each employee signing a separate employment contract with the employer - the number of options is reduced to one. In Estonia, where no special job-sharing regulation exists, the parties in an employment relationship may operate under either form of employment contract (separate or joint). Compared to the systems of the other MSs considered, where special job-sharing

49 Ettevõtete majandusnäitajad, 2014 ['The economic indicators, 2014'], p. 1. Available at http://www.stat.ee/78415?highlig ht=mikroettev\%C3\%B5tted (most recently accessed on 18.4.2017).

50 Eesti Statistika aastaraamat 2016 ['Estonian Statistics Yearbook 2016'], p. 215. Available at https://www.stat.ee/ valjaanne-2016_eesti-statistika-aastaraamat-2016 (most recently accessed on 18.4.2017).

51 Part-Time and Limited Term Employment Act of Germany (see Note 28), in Section 8, Subsection 4, stipulates that the legitimate reasons for rejection may be specified also in collective agreements. 
regulation exists, Estonian general labour law offers job-sharers more flexibility in the context of contractual choice. The plurality of contractual choice can increase the parties' options for entering a job-sharing regime, but at the same time it can promote unharmonised practice in implementation of job-sharing and create confusion related to the management of a joint employment contract.

Entrance into job-sharing is limited in those MSs, including Estonia, where the employers have been given the freedom to decline employees' applications for any reason. German practice should be followed if one wishes to avoid employers' exercise of 'self-will' in the transfer process and hence increase employees' options for moving over to job-sharing. 